\title{
VERY-LOW-CALORIE KETOGENIC DIETS WITH WHEY, VEGETABLE OR ANIMAL PROTEIN IN PATIENTS WITH OBESITY: A RANDOMIZED PILOT STUDY.
}

Sabrina Basciani ${ }^{1}$, Elisabetta Camajani ${ }^{1^{*}}$, Savina Contini ${ }^{1^{*}}$, Agnese Persichetti ${ }^{{ }^{*}}$, Renata Risi $^{1}$, Loris Bertoldi ${ }^{3}$, Lidia Strigari ${ }^{4}$, Giancarlo Prossomariti ${ }^{1}$, Mikiko Watanabe ${ }^{1}$, Stefania Mariani ${ }^{1}$, Carla Lubrano ${ }^{1}$, Alfredo Genco ${ }^{5}$, Giovanni Spera ${ }^{1}$, Lucio Gnessi'

${ }^{1}$ Department of Experimental Medicine, University of Rome “La Sapienza”, Rome, Italy ${ }^{2}$ Service of Pharmacovigilance, IRCCS-Regina Elena National Cancer Institute, Rome, Italy ${ }^{3}$ BMR Genomics s.r.l., Padova, Italy

${ }^{4}$ Department of Medical Physics, Policlinico S. Orsola-Malpighi, Bologna, Italy

${ }^{5}$ Department of Surgical Sciences, Surgical Endoscopy Unit, University of Rome "La Sapienza", Rome, Italy

${ }^{*}$ Authors contributed equally to this work

\section{Corresponding author:}

Lucio Gnessi, MD, PhD

Department of Experimental Medicine

University of Rome "La Sapienza",

Rome, Italy

e-mail: lucio.gnessi@uniroma1.it

phone: 0039.06.49970721

fax: 0039.06.4461450

(C) Endocrine Society 2020. All rights reserved. For permissions, please e-mail: journals.permissions@oup.com jc.2020-00128 See endocrine.org/publications for Accepted Manuscript disclaimer and additional information. 
Financial support. Financial support as well as meal replacement protein preparations were kindly provided by New Penta s.r.l. (Cuneo, Italy). The funding source had no involvement in the study design, recruitment of patients, study interventions, data collection, or interpretation of the results.

Disclosure Summary. The authors declare no conflicts of interest.

Trial Registration: This study was registered under ClinicalTrials.gov NCT04019431 
Abstract

Context

We compared the efficacy, safety and effect of 45-day isocaloric very-low-calorie ketogenic diets (VLCKDs) incorporating whey, vegetable or animal protein on the microbiota in patients with obesity and insulin resistance to test the hypothesis that protein source may modulate the response to VLCKD interventions.

Subjects and Methods

Forty-eight patients with obesity [ 19 males and 29 females, HOMA index $\geq 2.5$, age $56.2 \pm 6.1$ years, body mass index (BMI) $35.9 \pm 4.1 \mathrm{~kg} / \mathrm{m} 2$ ] were randomly assigned to three 45 -day isocaloric VLCKD regimens ( $\leq 800 \mathrm{kcal} /$ day) containing whey, plant or animal protein. Anthropometric indexes; blood and urine chemistry, including parameters of kidney, liver, glucose and lipid metabolism; body composition; muscle strength; and taxonomic composition of the gut microbiome were assessed. Adverse events were also recorded. Results

Body weight, BMI, blood pressure, waist circumference, HOMA index, insulin, and total and LDL cholesterol decreased in all patients. Patients who consumed whey protein had a more pronounced improvement in muscle strength. The markers of renal function worsened slightly in the animal protein group. A decrease in the relative abundance of Firmicutes and an increase in Bacteroidetes were observed after the consumption of VLCKDs. This pattern was less pronounced in patients consuming animal protein.

\section{Conclusions}

VLCKDs led to significant weight loss and a striking improvement in metabolic parameters over a 45-day period. VLCKDs based on whey or vegetable protein have a safer profile and result in a healthier microbiota composition than those containing animal proteins. VLCKDs incorporating whey protein are more effective in maintaining muscle performance.

Key words: Very low calorie ketogenic diet, VLCKD, obesity, whey proteins, vegetable proteins, animal proteins, intestinal microbiota, therapy 


\section{Introduction}

Obesity is strongly related to comorbidities, such as type 2 diabetes, inflammation, excess fat within the liver and pancreas, hypertension, and certain types of cancer $(1,2)$. Obesity management can delay the progression from prediabetes to type 2 diabetes (T2DM) and result in sustained remission of T2DM (3).

For many individuals with obesity and prediabetes, weight loss produces beneficial outcomes in regard to glycemic control, lipids, and blood pressure, and more intensive weight loss maximizes these benefits $(3,4)$. Despite the agreement on the important role of diet in treating insulin resistance and T2DM, there is little consensus about the optimal diet and ideal dietary macronutrient ratio (5). Weight loss and improvement in glucose homeostasis, including diabetes remission, were seen both after the consumption of a lowenergy diet (825-853 kcal/day) with a carbohydrate content that exceeded $50 \%$ of total calories (3) and after the consumption of very low-calorie diets (VLCDs) ( $\leq 800 \mathrm{kcal} / \mathrm{day})$ containing less than $30 \%$ carbohydrates/day (6). Recently, very-low-calorie ketogenic diets (VLCKDs) with $<50 \mathrm{~g}$ of carbohydrates/day were found to be associated with greater weight loss along with amelioration of glycemic control in subjects with T2DM compared with the effects of a standard care nutritional intervention (7-11). In patients with obesity who did not have diabetes, the effects of VLCKDs were found to be powerful in reducing plasma insulin levels (5). Furthermore, the source of dietary protein while following an energy-restricted diet was associated with benefits in body weight (BW) maintenance, blood pressure, insulin and homeostasis model assessment of insulin resistance (HOMA-IR) (12). Epidemiological studies indicate that diets containing whey proteins and vegetable proteins protect against obesity, whereas diets characterized by increased meat consumption are associated with greater weight gain (13). The mechanisms underlying these effects are not known. Interactions with the intestinal microbiota (14), appetite regulation $(15,16)$, effects on insulin and incretin secretion $(17-20)$, and palatability $(19,21)$ have been suggested as contributing 
factors that deserve in-depth analysis (22). We conducted a prospective pilot study comparing the efficacy and safety of VLCKDs incorporating either whey, plant or animal protein on metabolic and body composition parameters and on the composition of the gut microbiota in a population of patients with obesity and insulin resistance.

\section{MATERIALS AND METHODS}

\subsection{Study design and participants}

This was a prospective, open, nutritional intervention pilot study that enrolled patients with obesity and pharmacologically naïve insulin resistance among those attending the Center for the Study of Eating Disorders and Obesity, Department of Experimental Medicine, Section of Medical Pathophysiology, Food Science and Endocrinology of the University of Rome "La Sapienza", Italy. We compared VLCKDs based on whey protein [(16 patients, whey protein group (WPG)], vegetable protein [(16 patients, vegetable protein group (VPG)] or animal protein [(16 patients, animal protein group (APG)]. Eligible patients were randomly assigned (in a 1:1:1 ratio) through automated allocation. The primary outcome measure was change in BMI. Key secondary outcomes were changes in lipids, glucose, insulin resistance as estimated by HOMA-IR, IGF-1, body composition, muscle strength and composition of the gut microbiota. Male and postmenopausal female outpatients were eligible. The inclusion criteria were as follows: stable BW in the previous 3 months, age between 50 and 70 years, BMI between 30 and $40 \mathrm{~kg} / \mathrm{m}^{2}$, and HOMA-IR $\geq 2.5$. The exclusion criteria were the following conditions either self-reported or derived from medical records or examination: hypersensitivity to components used in the protocol products; renal, cardiac, cerebrovascular or gastrointestinal diseases; psychiatric disturbances; hydroelectrolytic alterations; type 1 diabetes; lack of informed consent; and bariatric surgery. Adverse events (AEs) were monitored throughout the treatment. This trial was registered at clinicaltrials.gov (NCT04019431). 


\subsection{Dietary interventions}

All patients followed a VLCKD $[780 \mathrm{kcal} / \mathrm{day}$, with the following composition in macronutrients, percentage of caloric intake and $\mathrm{g} / \mathrm{kg}$ of ideal BW of proteins (derived by the BMI set at $25 \mathrm{~kg} / \mathrm{m}^{2}$ ): carbohydrates $26 \mathrm{~g}(13.5 \%)$, olive oil $20 \mathrm{~g}$ plus $15 \mathrm{~g}$ of lipids from other sources (40.4\%), protein $90 \mathrm{~g}(46.1 \%, 1.2-1.4 \mathrm{~g} / \mathrm{kg})]$ for 45 days. The amount of protein was within the proposed essential composition of total diet replacements for weight control and was adjusted for the patients with overweight or obesity (23). WPG and VPG patients were given five meals/day [timing was at main meals (8 a.m., 1.00 p.m. and 8.00 pm), midmorning and mid-afternoon] containing whey protein (WPG) or vegetable protein derived from soya, green peas or cereals and one serving of vegetables with a low glycemic index at lunch and dinner (VPG). Patients in the APG were given five meals/day containing natural animal protein (meat, fish, eggs). Supplements containing vitamins, minerals and omega-3 fatty acids were provided in accordance with international recommendations (EFSA 2017, https://doi.org/10.2903/sp.efsa.2017.e15121). The diets were prepared by New Penta s.r.I. (Cuneo, Italy) following the indications of nutritionists and were delivered in preassembled boxes.

Participants received counseling by physicians and nutrition experts at baseline (T0) and every two weeks up to day 45 (T45); dietary compliance was also assessed. Participants were encouraged to exercise for 30 minutes at least 3 times weekly, but no formal exercise program or incentives were provided.

\subsection{Anthropometric assessment}

BW, height, systolic and diastolic blood pressure (BP), waist circumference (WC), thigh circumference (TC) and hip circumference $(\mathrm{HC})$ were measured at T0 and every two weeks. Anthropometric measurements were recorded after an overnight fast under resting conditions using calibrated equipment. BW was measured using a balance-beam scale (Seca $\mathrm{GmbH} \& \mathrm{Co}$ ). Systolic and diastolic blood pressure were 
measured using a mercury-gravity manometer. Height was rounded to the closest $0.5 \mathrm{~cm}$. BMI was calculated as weight divided by squared height in meters $\left(\mathrm{kg} / \mathrm{m}^{2}\right)$. WC was measured midway between the costal arch and the iliac crest, HC was measured at the symphysis-greater trochanter level to the closest $1.0 \mathrm{~cm}$, and TC was measured directly below the gluteal fold of the right thigh.

\subsection{Blood and urine chemistry}

Blood count (ADVIA 2120i Hematology System, Siemens Healthcare s.r.l., Italy), electrolytes [chloride, potassium and sodium (indirect ion-selective electrode potentiometry), calcium and magnesium (colorimetric assay)], glucose (enzymatic colorimetric assay), insulin (electrochemiluminescence immunoassay), lipids [(triglycerides, total, HDL and LDL cholesterol) (enzymatic colorimetric assay)], total protein and albumin (capillary system), C-reactive protein (CRP) (immunoturbidimetric assay), erythrocyte sedimentation rate (ESR) (capillary photometric assay), plasma creatinine (kinetic colorimetric compensated Jaffé method), blood urea nitrogen (BUN), uric acid, alanine transferase (ALT) and aspartate transaminase (AST) (enzymatic colorimetric assay), and estimated glomerular filtration rate (eGFR) were determined at baseline and T45. All analyses were performed on a COBAS 6000 (Roche Diagnostics, Risch-Rotkreuz, Switzerland) and on CapillarysR Systems (Sebia, Evry, France).

The hepatic steatosis index (HSI), a noninvasive screening tool for hepatic steatosis, was calculated according to Lee et al. (24). IGF-1 plasma levels were measured after an overnight fast using commercial ELISA assay kits (R\&D Systems, Inc., Minneapolis, MN, USA). Insulin resistance was determined using HOMA-IR (25). The semiquantitative concentration of acetoacetic acid was measured in the first 
morning urine at baseline and every week until the end of the study by the patients (Ketur-Test, Accu-Chek, Roche Diagnostics, Italy).

\subsection{Dual-energy X-ray absorptiometry measurement (DEXA)}

Body composition, total and regional body fat mass and fat-free mass were measured by DEXA (Hologic 4500, Bedford, MA, USA) at baseline and at the end of the trial. Trunk fat was defined as the adipose tissue localized within the region below the chin, delineated by vertical lines within the left and right glenoid fossae bordering laterally to the ribs and by the oblique lines that cross the femoral necks and converge below the pubic symphysis.

\subsection{Muscular strength}

Handgrip strength $(\mathrm{HG})$ was measured with a digital dynamometer (DynEx, Akern, Pontassieve, FI, Italy) at T0 and T45 with the patients seated, shoulder adducted and forearms resting flat on the chair arms. Before starting, patients were asked to squeeze the dynamometer as hard as possible for at least 3 seconds. Three measurements were repeated with both the dominant and nondominant arms. The highest value measured was recorded.

\subsection{Taxonomic composition of the gut microbiome}

Fecal sampling was performed using a sterile swab (FLmedical, Italy) and tubes (Starlab Group, Italy) in the morning of the day of initiating the VLCKD and at T45; the samples were put on ice immediately after collection, brought to the hospital within $2 \mathrm{~h}$, and stored at $-80^{\circ} \mathrm{C}$. The samples were transferred to the laboratory on dry ice within $24 \mathrm{~h}$ of collection and stored at $-80^{\circ} \mathrm{C}$ until DNA extraction. DNA was extracted using the Cador Pathogen 96 QIAcube HT Kit (Qiagen srl, Italy) with lysis step modification according to the Mobio PowerFecal kit (Qiagen). The V3-V4 regions of the $16 \mathrm{~S}$ ribosomal RNA gene were amplified using the Illumina tailed 
primers Pro341F (5'-TCGTCGGCAGCGTCAGATGTGTATAAGAGACAGCCTACGGG AGGCAGCA-3') and Pro805R (5'GTCTCGTGGGCTCGGAGATGTGTATAAGAGA

GACTACNVGGGTATCTAATCC-3') using Platinum Taq (Thermo Fisher Scientific Inc, USA) to conduct PCR $\left(94^{\circ} \mathrm{C}\right.$ for 2 min, followed by 25 cycles at $94^{\circ} \mathrm{C}$ for $30 \mathrm{~s}$, $55^{\circ} \mathrm{C}$ for $30 \mathrm{~s}$, and $68^{\circ} \mathrm{C}$ for $30 \mathrm{~s}$, and a final extension at $68^{\circ} \mathrm{C}$ for 7 min). PCR amplicons were purified with Agencourt AMPure XP Beads 0.8X (Beckman Coulter, Inc., CA, USA) and amplified following the Nextera XT Index protocol (Illumina, Inc., CA, USA). The purified amplicons were normalized by SequalPrep ${ }^{\mathrm{TM}}$ Normalization Plate Kit (Thermo Fisher Scientific Inc.) and multiplexed. The pool was purified with 1X Magnetic Beads Agencourt XP (Beckman Coulter, Inc.) loaded on the MiSeq System (Illumina, Inc.) and sequenced following the V3 - 300PE strategy. The bioinformatic analysis was performed by Qiime2 (26). Raw reads were first trimmed by applying Cutadapt to remove residual primer sequences and then processed with DADA2 plug-in to perform the denoising step $(27,28)$. DADA2 was run with default parameters except for the truncation length: forward and reverse reads were truncated at 270 and 260 nucleotides, respectively. The resulting amplicon sequence variant (ASV) sequences were filtered out by applying a $0.005 \%$ frequency threshold to discard singletons and very rare sequences. Greengeens v.13-8 and Silva v.132 databases were used to associate the taxonomy to the remaining ASVs.

\subsection{Questionnaires}

Adherence to the dietary interventions was evaluated through a daily food diary. Safety was monitored throughout the trial based on the reported AEs either collected spontaneously or actively assessed by the investigators. Quality of life was assessed through the SF-36 questionnaire every two weeks. Vivacity, agitation, sadness, calmness, energy, discouragement, happiness, and satiety were evaluated using a 5-point scale. 


\subsection{Data management and statistical methods}

Data are expressed as the mean values \pm SDs or percentages where appropriate. Comparisons between groups were evaluated using Student's $t$ test. Differences between groups were tested by ANOVA, and for differences 0-45, an ANCOVA model was used when a significant group effect was observed. A Tukey post hoc test was used for multiplecomparison purposes in the case of $F$ significant values. The number of subjects was identified considering the number of subjects generally included in similar published pilot studies (29-32). Assuming a power of 0.80 and alpha of 0.05 , 48 participants (total sample size, 16 participants in each of 3 groups) were considered appropriate to highlight an effect size of 0.46 (high). Differences were considered statistically significant when $P$ was $\leq 0.05$. Since this was a pilot study, we also reported values with $P<0.1$ as "trending towards significance". Statistical analysis was carried out using R-package version 3.6.3.

\subsection{Ethical aspects}

The study protocol was approved by the Ethics Committee of the University of Rome "La Sapienza" (code 3920) and was conducted in accordance with the Declaration of Helsinki and Good Clinical Practice. All patients were informed about the possible risks and benefits of the proposed interventions and provided written consent.

\section{RESULTS}

We screened 350 patients with obesity for eligibility from January 2019 to June 2019 . We enrolled and randomized 48 participants. Sixteen patients were allocated to the VLCKD with whey protein group (WPG), 16 to the VLCKD with vegetable protein group (VPG), and 16 to the VLCKD with animal protein group (APG) (Fig. 1). All the participants were followed up to the completion of the study. The baseline characteristics of the patients were similar between groups and are summarized in table 1. Compliance was comparable in all groups. 
Urine acetoacetic acid, reflecting ketosis, increased significantly from baseline to the end of the VLCKD interventions (table 1), and a plateau value was reached after 7 days in all groups (data not shown).

We recorded a significant reduction in initial BW both in the WPG and the VPG at T45. A reduction in BW was also observed in the APG $(-6.4 \pm 2.4 \mathrm{~kg}$ compared to baseline, range 2.0/-11.1 kg, average percent BW loss $-6.5 \%$, although it did not reach statistical significance. BMI followed the same pattern, with the exception that the improvement in BMI was statistically significant in the APG as well. Significant reductions in WC and systolic and diastolic blood pressure were recorded in all groups. $\mathrm{HC}$ and TC reductions were observed in all groups and reached significance in the VPG and the APG and the WPG and the VPG, respectively.

A significant reduction in fasting glycemia, fasting insulin and HOMA-IR was observed in all groups, with the exception of fasting glycemia in the VPG. Circulating IGF-1 levels increased in the WPG and decreased in the VPG. The increase in IGF-1 seen in the APG was not statistically significant.

A decreasing trend in total fat and trunk fat mass was consistently recorded, although the significance was seen only for trunk fat mass in the WPG and the VPG. A relative increase in the percentage of lean mass was also seen consistently. Electrolytes (data not shown) and liver function tests did not change during the study within groups. Small, nonsignificant variations in plasma creatinine values were observed in all groups. Of note, in the APG, blood urea nitrogen and uric acid increased while eGFR decreased significantly compared with baseline. Urinary $\mathrm{pH}$ values varied within the normal reference intervals (data not shown). At the baseline visit, no ketosis was recorded. The mean values of urinary acetoacetic acid increased from T0 to T45 in all groups (table 1).

The HSI was slightly reduced at T45; however, the difference was significant only for VPG. All groups experienced a profound reduction in total cholesterol, LDL cholesterol and 
triglycerides. Despite a strong improvement in the inflammatory markers ESR and CRP, changes in these measures did not show statistical significance. HG did not change during the observation period in any of the groups.

The $\mathrm{P}$ values of multiple comparisons of delta percent variations in the measured parameters between groups that were statistically significant are shown in table 2. No differences were seen for the majority of parameters, with the exception of IGF-1, creatinine, eGFR, blood urea, uric acid and HG, whose variations differed between groups. Figure 2 shows the box plot of the within-group percent change values from baseline. Although the variations remained within the normal range, the group of patients who consumed a VLCKD containing animal protein (APG) showed an increase in creatinine levels and a significant reduction in eGFR compared to the same parameters of the other two treatment groups. The delta percent increase in BUN was more pronounced in the WPG and the APG, while uric acid increased more in the VPG. HG was maintained to a greater extent in the WPG than in the VPG. The delta percent increase in IGF-1 values was more pronounced in the WPG and the APG than in the VPG.

The dominant phyla in the fecal samples of the patients at T0 were Firmicutes, Bacteroidetes, Proteobacteria, Verrucomicrobia, Fusobacteria, and Actinobacteria (Fig. 3A). The relative abundance of Firmicutes was significantly diminished, and that of Bacteroidetes increased proportionally 45 days after the initiation of the VLCKDs (Fig. 3B). The mean relative abundance of Proteobacteria also increased, while that of Actinobacteria decreased (data not shown). The abundance of the two predominant bacterial divisions (Firmicutes and Bacteroidetes) was almost superimposable in the three dietary intervention groups of patients at baseline, with no differences according to multiple comparison (Fig. 4). Over time, the relative abundance of Bacteroidetes increased, and the abundance of Firmicutes significantly decreased, irrespective of diet type, with the only exception in the VPG, in which the increase in Bacteroidetes did not reach statistical significance (Fig. 4). To verify whether the different protein sources in the VLCKDs could influence the variation in the abundance of 
Firmicutes and Bacteroidetes, a two-way ANOVA test was performed. The increase in Bacteroidetes and the decrease in Firmicutes were influenced by the protein composition of the diets. In particular, whey protein and vegetable protein were more potent in reducing the percentage of Firmicutes than the dietary intervention incorporating animal protein. Regarding the Bacteroidetes gut microbiota content, a significant difference was only observed between the individuals exposed to the diets incorporating whey protein and vegetable protein, with the VLCKD containing whey protein exhibiting a more potent ability to increase the percentage of total sequences of Bacteroidetes.

The AEs were mild; in fact, none of the patients dropped out of the study, and the differences between the diet interventions were negligible (table 3 shows the most frequent side effects and the number of participants reporting them). During ketosis, the intragroup variation as well as the intergroup variation in the quality of life scores did not change (data not shown).

\section{DISCUSSION}

Our data show that a 45-day-long VLCKD causes a profound reduction in BW and improves glycemic control, lipid metabolism and arterial pressure in patients with obesity and insulin resistance. The VLCKD is safe and well tolerated; the gut microbiota composition is influenced by the VLCKD, and the source of dietary protein modulates the variation in the gut microbiota caused by the VLCKD. Whey protein intake contributes more substantially to the preservation of muscle performance.

These results provide important implications. First, VLCKDs may hold promise as a strategy to simultaneously improve glycemic control while facilitating profound weight loss in patients with insulin resistance. All individuals who consumed VLCKDs showed a decrease in fasting plasma glucose, insulin and HOMA-IR. Of note, no episodes of hypoglycemia were 
observed. Numerous studies on VLCKDs have shown diabetes improvement and remission $(8,9,11,33)$. Here, we show that this pattern applies to individuals with insulin resistance as well. We hypothesize that the improvement in carbohydrate metabolism might correlate with both weight loss and low sugar content, although additional mechanisms cannot be excluded (34). The short duration of our intervention prevents the assessment of the durability of the effect.

An important concern with low carbohydrate diets is the potential negative impact on lipid metabolism due to the increased proportion of calories coming from fat. Clearly, this does not apply to a 45-day VLCKD, for which the daily lipid intake is still low, as can be inferred by the profound reduction in the circulating cholesterol and triglyceride levels measured in our patients. Many other mechanisms may contribute to the reduction in circulating lipids, such as the improvement in insulin resistance with positive effects on lipid metabolism through the action on HMG-CoA reductase and striking effects on lipoprotein size and subclass particle concentrations (35). Moreover, it has been reported that even high-fat ketogenic diets are capable of ameliorating nonalcoholic fatty liver disease through de novo lipogenesis inhibition and fatty acid oxidation induction, leading to weight loss and reduced hepatic fat content. It is therefore unsurprising that serum triglycerides, well-established markers of liver fat, are almost invariably reduced upon the adoption of any kind of ketogenic diet (36).

Many studies have shown that dietary protein content may play a role in weight management (37-39). Much less is known about the importance of the sources from which these proteins are derived (40). In the face of significant variations in the anthropometric measures between T0 and T45 within each group, the intake of different kinds of protein was not associated with meaningful changes in BW, WC, BMI or the remaining anthropometric parameters among groups. Some differences that might have clinical significance reflect the proportion of lean and fat mass in different body regions. The loss of trunk fat mass was less pronounced in the group of patients who consumed animal protein. However, the betweengroup comparison of trunk fat content did not reveal a significant difference. 
Analogous to a previous report (32), crude HG did not vary significantly during our dietary intervention. This is notable due to the well-known cardiovascular advantages of maintaining muscle strength (41-42). Interestingly, the individuals fed whey protein preserved their HG strength to a greater extent than in the vegetable protein-fed group. Whether this is due to the higher relative increase in IGF-1 levels associated with whey protein consumption is unclear. Our data are in line with the reported association between protein intake, largely attributable to milk intake, and circulating IGF-1 levels, an association that has been related to muscle strength (43-44). Our evidence is purely associative, and many other mechanisms, including neural mechanisms, learning effects, and improvement in the actinmyosin machinery, among others, may explain this finding. Furthermore, our measurements, although accurately conducted, suffer from the variation in current methods of assessing grip strength (45); thus, an analysis of a larger sample is warranted.

The intestinal microbiota is relatively stable throughout adult life (46-48). Each individual has his or her own unique microbial community whose profile is stable over time. However, much is still unknown regarding how stable the microbiota is to perturbations, such as those arising from antibiotics, diet and the immune system. KDs influence the taxonomic and functional composition of the gut microbiota with mixed contradictory results (49). We observed a pattern in the variation in the microbiota that resembled that in children affected by refractory epilepsy treated with KDs, with increased amounts of Bacteroides and decreased amounts in Firmicutes $(50,51)$. Moreover, we found divergent responses to VLCKDs containing protein from different sources with substantial effects on the Firmicutes-to-Bacteroidetes ratio. Recent evidence suggests that the quality of dietary protein may impact the gut environment, shaping the microbiota and the host-microbe (co)metabolic pathways and products and linking protein-dependent changes in the obese gut microbiota $(52,53)$. The gut microbiota composition in mice (54), rats (55), and piglets (56) revealed divergent responses to diets containing protein from different sources. Although the prospect of healthinterpretable microbiota data is exciting $(57,58)$, and despite a decade of research 
establishing a strong association between the gut microbiota and various diseases, including obesity and diabetes, in humans a causal relationship and the underlying mechanism remain unknown (59-61). The strongest effect of the VLCKD containing whey protein in reducing Firmicutes and increasing Bacteroidetes compared with the vegetable- and animalcontaining VLCKDs observed here warrants further investigation.

The profound metabolic effects associated with VLCKDs were observed in the absence of serious AEs that were previously associated with VLCKD interventions $(8,49,62,63)$. Quality of life score variations were negligible.

Regarding the potential issues of our pilot study, the number of subjects enrolled was small, although sufficient, to appreciate the variations induced by VLCKDs. The short duration is a further limitation together with the lack of follow-up. Moreover, the measurement of capillary blood concentration of beta hydroxybutyrate would have been a more accurate method of ketosis assessment than the urinary acetoacetate semiquantitative determination used in this study for technical reasons. However, the fundamental objectives that our study had set were achieved, and the additional information obtained will certainly lead to further investigation.

In summary, these data show that a 45-day-long VLCKD is safe and quickly reduces weight and fasting glycemia in patients with obesity and insulin resistance. The investigated protein sources did not differentially impact anthropometric or metabolic parameters under the acute conditions of the intervention in our experimental design. However, whey proteins and vegetable proteins showed a safer profile and directed the intestinal microbiota towards a healthier composition. 


\section{ACKNOWLEDGMENTS}

The authors would like to thank Dr Settimia Di Bernardo and Dr Maria Faro for their contribution in the management of the patients.

\section{DATA AVAILABILITY}

The datasets generated and/or analyzed during the current study are not publicly available but are available from the corresponding author on reasonable request.

\section{AUTHOR CONTRIBUTIONS}

The author contributions to the paper were as follows. Study concept: SB and GS; design: S.B., G.S., and L.G.; acquisition of data: SB, SC, AP, EC, LB, RR, GP, and MW; interpretation of the data: SM, CL, AG, MW, and LS; analysis: LS, LB, and AP; writing of the manuscript: SB, EC, AP, and LG; all authors approved the final version of the manuscript. 


\section{REFERENCES}

1. GBD 2015 Obesity Collaborators, Afshin A, Forouzanfar MH, Reitsma MB, Sur P, Estep K, Lee A, Marczak L, Mokdad AH, Moradi-Lakeh M, Naghavi M, Salama JS, Vos T, Abate $\mathrm{KH}$, Abbafati C, Ahmed MB, Al-Aly Z, Alkerwi A, Al-Raddadi R, Amare AT, Amberbir A, Amegah AK, Amini E, Amrock SM, Anjana RM, Ärnlöv J, Asayesh H, Banerjee A, Barac A, Baye E, Bennett DA, Beyene AS, Biadgilign S, Biryukov S, Bjertness E, Boneya DJ, Campos-Nonato I, Carrero JJ, Cecilio P, Cercy K, Ciobanu LG, Cornaby L, Damtew SA, Dandona L, Dandona R, Dharmaratne SD, Duncan BB, Eshrati B, Esteghamati A, Feigin VL, Fernandes JC, Fürst T, Gebrehiwot TT, Gold A, Gona PN, Goto A, Habtewold TD, Hadush KT, Hafezi-Nejad N, Hay SI, Horino M, Islami F, Kamal R, Kasaeian A, Katikireddi SV, Kengne AP, Kesavachandran CN, Khader YS, Khang YH, Khubchandani J, Kim D, Kim YJ, Kinfu Y, Kosen S, Ku T, Defo BK, Kumar GA, Larson HJ, Leinsalu M, Liang X, Lim SS, Liu P, Lopez AD, Lozano R, Majeed A, Malekzadeh R, Malta DC, Mazidi M, McAlinden C, McGarvey ST, Mengistu DT, Mensah GA, Mensink GBM, Mezgebe HB, Mirrakhimov EM, Mueller UO, Noubiap JJ, Obermeyer CM, Ogbo FA, Owolabi MO, Patton GC, Pourmalek F, Qorbani M, Rafay A, Rai RK, Ranabhat CL, Reinig N, Safiri S, Salomon JA, Sanabria JR, Santos IS, Sartorius B, Sawhney M, Schmidhuber J, Schutte AE, Schmidt MI, Sepanlou SG, Shamsizadeh M, Sheikhbahaei S, Shin MJ, Shiri R, Shiue I, Roba HS, Silva DAS, Silverberg JI, Singh JA, Stranges S, Swaminathan S, Tabarés-Seisdedos R, Tadese F, Tedla BA, Tegegne BS, Terkawi AS, Thakur JS, Tonelli M, Topor-Madry R, Tyrovolas S, Ukwaja KN, Uthman OA, Vaezghasemi M, Vasankari T, Vlassov VV, Vollset SE, Weiderpass E, Werdecker A, Wesana J, Westerman R, Yano Y, Yonemoto N, Yonga G, Zaidi Z, Zenebe ZM, Zipkin B, Murray CJL. Health Effects of Overweight and Obesity in 195 Countries over 25 Years. N Engl J Med. 2017;377:13-27. 
2. Apovian CM. Obesity: definition, comorbidities, causes, and burden. Am J Manag Care. 2016;22:s176-185.

3. Lean ME, Leslie WS, Barnes AC, Brosnahan N, Thom G, McCombie L, Peters C, Zhyzhneuskaya S, Al-Mrabeh A, Hollingsworth KG, Rodrigues AM, Rehackova L, Adamson AJ, Sniehotta FF, Mathers JC, Ross HM, Mcllvenna Y, Stefanetti R, Trenell M, Welsh P, Kean S, Ford I, McConnachie A, Sattar N, Taylor R. Primary care-led weight management for remission of type 2 diabetes (DiRECT): an open-label, cluster-randomised trial. Lancet. 2018;391:541-551.

4. Norris SL, Zhang X, Avenell A, Gregg E, Bowman B, Schmid CH, Lau J. Long-term effectiveness of weight-loss interventions in adults with pre-diabetes: a review. Am J Prev Med. 2005;28:126-139.

5. Caprio M, Infante M, Moriconi E, Armani A, Fabbri A, Mantovani G, Mariani S, Lubrano C, Poggiogalle E, Migliaccio S, Donini LM, Basciani S, Cignarelli A, Conte E, Ceccarini G, Bogazzi F, Cimino L, Condorelli RA, La Vignera S, Calogero AE, Gambineri A, Vignozzi L, Prodam F, Aimaretti G, Linsalata G, Buralli S, Monzani F, Aversa A, Vettor R, Santini F, Vitti P, Gnessi L, Pagotto U, Giorgino F, Colao A, Lenzi A; Cardiovascular Endocrinology Club of the Italian Society of Endocrinology. Very-low-calorie ketogenic diet (VLCKD) in the management of metabolic diseases: systematic review and consensus statement from the Italian Society of Endocrinology (SIE). J Endocrinol Invest. 2019;42:1365-1386.

6. Feinman RD, Pogozelski WK, Astrup A, Bernstein RK, Fine EJ, Westman EC, Accurso A, Frassetto L, Gower BA, McFarlane SI, Nielsen JV, Krarup T, Saslow L, Roth KS, Vernon MC, Volek JS, Wilshire GB, Dahlqvist A, Sundberg R, Childers A, Morrison K, Manninen AH, Dashti HM, Wood RJ, Wortman J, Worm N. Dietary carbohydrate restriction as the first approach in diabetes management: critical review and evidence base. Nutrition. 2015;31:113. 
7. Willi SM, Martin K, Datko FM, Brant BP. Treatment of type 2 diabetes in childhood using a very-low-calorie diet. Diabetes Care 2004;27:348-353.

8. Goday A, Bellido D, Sajoux I, Crujeiras AB, Burguera B, García-Luna PP, Oleaga A, Moreno B, Casanueva FF. Short-term safety, tolerability and efficacy of a very low-calorieketogenic diet interventional weight loss program versus hypocaloric diet in patients with type 2 diabetes mellitus. Nutr Diabetes 2016;6:e230.

9. Hussain TA, Mathew TC, Dashti AA, Asfar S, Al-Zaid N, Dashti HM. Effect of low-calorie versus low-carbohydrate ketogenic diet in type 2 diabetes. Nutrition 2012;28:1016-1021.

10. Westman EC, Yancy WS Jr, Mavropoulos JC, Marquart M, McDuffie JR. The effect of a low-carbohydrate, ketogenic diet versus a low-glycemic index diet on glycemic control in type 2 diabetes mellitus. Nutr Metab (Lond) 2008;5:36.

11. Romano L, Marchetti M, Gualtieri P, Di Renzo L, Belcastro M, De Santis GL, Perrone MA, De Lorenzo A. Effects of a Personalized VLCKD on Body Composition and Resting Energy Expenditure in the Reversal of Diabetes to Prevent Complications. Nutrients 2019;11: E1526.

12. van Baak MA, Larsen TM, Jebb SA, Martinez A, Saris WHM, Handjieva-Darlenska T, Kafatos A, Pfeiffer AFH, Kunešová M, Astrup A. Dietary intake of protein from different sources and weight regain, changes in body composition and cardiometabolic risk factors after weight loss: the DIOGenes study. Nutrients 2017;9: E1326.

13. Mozaffarian D. Dietary and Policy Priorities for Cardiovascular Disease, Diabetes, and Obesity: A Comprehensive Review. Circulation 2016;133:187-225.

14. David LA, Maurice CF, Carmody RN, Gootenberg DB, Button JE, Wolfe BE, Ling AV,Devlin AS, Varma Y, Fischbach MA, Biddinger SB, Dutton RJ, Turnbaugh PJ. Diet rapidly and reproducibly alters the human gut microbiome. Nature 2014; 23: 559-563. 
15. Bendtsen LQ, Lorenzen JK, Bendsen NT, Rasmussen C, Astrup A. Effect of dairy proteins on appetite, energy expenditure, body weight, and composition: a review of the evidence from controlled clinical trials. Adv Nutr 2013; 4:418-438.

16. Neacsu M, Fyfe C, Horgan G, Johnstone AM. Appetite control and biomarkers of satiety with vegetarian (soy) and meat-based high-protein diets for weight loss in obese men: a randomized crossover trial. Am J Clin Nutr 2014; 100:548-558

17. Jakubowicz D, Froy O, Ahrén B, Boaz M, Landau Z, Bar-Dayan Y, Ganz T, Barnea M, Wainstein J. Incretin, insulinotropic and glucose-lowering effects of whey protein pre-load in type 2 diabetes: a randomised clinical trial. Diabetologia 2014; 57:1807-1811.

18. Viguiliouk E, Stewart SE, Jayalath VH, Ng AP, Mirrahimi A, de Souza RJ, Hanley AJ, Bazinet RP, Blanco Mejia S, Leiter LA, Josse RG, Kendall CW, Jenkins DJ, Sievenpiper JL. Effect of Replacing Animal Protein with Plant Protein on Glycemic Control in Diabetes: A Systematic Review and Meta-Analysis of Randomized Controlled Trials. Nutrients 2015; 1:9804-9824.

19. Hutchison AT, Piscitelli D, Horowitz M, Jones KL, Clifton PM, Standfield S, Hausken T, Feinle-Bisset C, Luscombe-Marsh ND. Acute load-dependent effects of oral whey protein on gastric emptying, gut hormone release, glycemia, appetite, and energy intake in healthy men. Am J Clin Nutr 2015; 102:1574-1584.

20. Klementova M, Thieme L, Haluzik M, Pavlovicova R, Hill M, Pelikanova T, Kahleova H. A Plant-Based Meal Increases Gastrointestinal Hormones and Satiety More Than an Energyand Macronutrient-Matched Processed-Meat Meal in T2D, Obese, and Healthy Men: A Three-Group Randomized Crossover Study. Nutrients. 2019; 11:pii: E157.

21. Flaim C, Kob M, Di Pierro AM, Herrmann M, Lucchin L. Effects of a whey protein supplementation on oxidative stress, body composition and glucose metabolism among 
overweight people affected by diabetes mellitus or impaired fasting glucose: A pilot study. $\mathrm{J}$ Nutr Biochem 2017; 50:95-102.22.

22. Comerford KB, Pasin G. Emerging Evidence for the Importance of Dietary Protein Source on Glucoregulatory Markers and Type 2 Diabetes: Different Effects of Dairy, Meat, Fish, Egg, and Plant Protein Foods. Nutrients 2016;8:E446.

23. EFSA Panel on Dietetic Products, Nutrition and Allergies (NDA). Scientific opinion on the essential composition of total diet replacements for weight control. EFSA J 2015;13:3957.

24. Lee JH, Kim D, Kim HJ, Lee CH, Yang JI, Kim W, Kim YJ, Yoon JH, Cho SH, Sung MW, Lee HS. Hepatic steatosis index: a simple screening tool reflecting nonalcoholic fatty liver disease. Dig Liver Dis 2010;42:503-508.

25. Matthews DR, Hosker JP, Rudenski AS, Naylor BA, Treacher DF, Turner RC.Homeostasis model assessment: insulin resistance and beta - cell function from fasting plasma glucose and insulin concentrations in man. Diabetologia 1985;28:412-419.

26. Bolyen E, Rideout JR, Dillon MR, Bokulich NA, Abnet CC, Al-Ghalith GA, Alexander H, Alm EJ, Arumugam M, Asnicar F, Bai Y, Bisanz JE, Bittinger K, Brejnrod A, Brislawn CJ, Brown CT, Callahan BJ, Caraballo-Rodríguez AM, Chase J, Cope EK, Da Silva R, Diener C, Dorrestein PC, Douglas GM, Durall DM, Duvallet C, Edwardson CF, Ernst M, Estaki M, Fouquier J, Gauglitz JM, Gibbons SM, Gibson DL, Gonzalez A, Gorlick K, Guo J, Hillmann B, Holmes S, Holste H, Huttenhower C, Huttley GA, Janssen S, Jarmusch AK, Jiang L, Kaehler BD, Kang KB, Keefe CR, Keim P, Kelley ST, Knights D, Koester I, Kosciolek T, Kreps J, Langille MGI, Lee J, Ley R, Liu YX, Loftfield E, Lozupone C, Maher M, Marotz C, Martin BD, McDonald D, Mclver LJ, Melnik AV, Metcalf JL, Morgan SC, Morton JT, Naimey AT, Navas-Molina JA, Nothias LF, Orchanian SB, Pearson T, Peoples SL, Petras D, Preuss ML, Pruesse E, Rasmussen LB, Rivers A, Robeson MS 2nd, Rosenthal P, Segata N, Shaffer M, Shiffer A, Sinha R, Song SJ, Spear JR, Swafford AD, Thompson LR, Torres PJ, Trinh P, 
Tripathi A, Turnbaugh PJ, Ul-Hasan S, van der Hooft JJJ, Vargas F, Vázquez-Baeza Y, Vogtmann E, von Hippel M, Walters W, Wan Y, Wang M, Warren J, Weber KC, Williamson CHD, Willis AD, Xu ZZ, Zaneveld JR, Zhang Y, Zhu Q, Knight R, Caporaso JG. Reproducible, interactive, scalable and extensible microbiome data science using QIIME 2. Nat Biotechnol. 2019;37:852-857.

27. Martin M. Cutadapt removes adapter sequences from high-throughput sequencing reads. EMBnet. journal 2011;17:10-12.

28. Callahan BJ, McMurdie PJ, Rosen MJ, Han AW, Johnson AJ, Holmes SP. DADA2: Highresolution sample inference from Illumina amplicon data. Nat Methods 2016;13:581-583.

29. Sajoux I, Lorenzo PM, Gomez-Arbelaez D, Zulet MA, Abete I, Castro AI, Baltar J, Portillo MP, Tinahones FJ, Martinez JA, Crujeiras AB, Casanueva FF. Effect of a Very-Low-Calorie Ketogenic Diet on Circulating Myokine Levels Compared with the Effect of Bariatric Surgery or a Low-Calorie Diet in Patients with Obesity. Nutrients 2019;11: pii: E2368.

30. Gomez-Arbelaez D, Crujeiras AB, Castro AI, Goday A, Mas-Lorenzo A, Bellon A, Tejera C, Bellido D, Galban C, Sajoux I, Lopez-Jaramillo P, Casanueva FF. Acid-base safety during the course of a very low-calorie-ketogenic diet. Endocrine 2017;58:81-90.

31. Basciani S, Costantini D, Contini S, Persichetti A, Watanabe M, Mariani S, Lubrano C, Spera G, Lenzi A, Gnessi L. Safety and efficacy of a multiphase dietetic protocol with meal replacements including a step with very low calorie diet. Endocrine 2015;48:863-70.

32. Gomez-Arbelaez D, Bellido D, Castro Al, Ordoñez-Mayan L, Carreira J, Galban C, Martinez-Olmos MA, Crujeiras AB, Sajoux I, Casanueva FF. Body Composition Changes After Very-Low-Calorie Ketogenic Diet in Obesity Evaluated by 3 Standardized Methods. J Clin Endocrinol Metab 2017;102:488-498. 
33. Westman EC, Tondt J, Maguire E, Yancy WS Jr. Implementing a low-carbohydrate, ketogenic diet to manage type 2 diabetes mellitus. Expert Rev Endocrinol Metab 2018;13:263-272.

34. Bolla AM, Caretto A, Laurenzi A, Scavini M, Piemonti L. Low-Carb and Ketogenic Diets in Type 1 and Type 2 Diabetes. Nutrients 2019;11:962.

35. Vergès B. Pathophysiology of diabetic dyslipidaemia: where are we? Diabetologia 2015;58:886-899.

36. Watanabe M, Tozzi R, Risi R, Tuccinardi D, Mariani S, Basciani S, Spera G, Lubrano C, Gnessi L. Beneficial effects of the ketogenic diet on nonalcoholic

fatty liver disease: A comprehensive review of the literature. Obes Rev. 2020 Mar

24.

37. Wadden TA, Hollander P, Klein S, Niswender K, Woo V, Hale PM, Aronne L; NN80221923 Investigators. Weight maintenance and additional weight loss with liraglutide after lowcalorie-diet-induced weight loss: the SCALE Maintenance randomized study. Int $\mathrm{J}$ Obes (Lond). 2013;37:1443-1451.

38. Larsen TM, Dalskov SM, van Baak M, Jebb SA, Papadaki A, Pfeiffer AF, Martinez JA, Handjieva-Darlenska T, Kunešová M, Pihlsgård M, Stender S, Holst C, Saris WH, Astrup A. Diet, Obesity, and Genes (Diogenes) Project. Diets with high or low protein content and glycemic index for weight-loss maintenance. N Engl J Med 2010;363:2102-2113.

39. Aller EE, Larsen TM, Claus H, Lindroos AK, Kafatos A, Pfeiffer A, Martinez JA, Handjieva-Darlenska T, Kunesova M, Stender S, Saris WH, Astrup A, van Baak MA. Weight loss maintenance in overweight subjects on ad libitum diets with high or low protein content and glycemic index: the DIOGENES trial 12-month results. Int J Obes (Lond) 2014;38:15111517. 
40. Gilbert, J.A.; Bendsen, N.T.; Tremblay, A.; Astrup, A. Effect of proteins from different sources on body composition. Nutr Metab Cardiovasc Dis 2011;21:B16-B31

41. Leong DP, Teo KK, Rangarajan S, Lopez-Jaramillo P, Avezum A Jr, Orlandini A, Seron P, Ahmed SH, Rosengren A, Kelishadi R, Rahman O, Swaminathan S, Iqbal R, Gupta R, Lear SA, Oguz A, Yusoff K, Zatonska K, Chifamba J, Igumbor E, Mohan V, Anjana RM, Gu H, Li W, Yusuf S; Prospective Urban Rural Epidemiology (PURE) Study investigators. Prognostic value of grip strength: findings from the Prospective Urban Rural Epidemiology (PURE) study. Lancet 2015;386:266-273.

42. Lopez-Jaramillo P, Cohen DD, Gómez-Arbeláez D, Bosch J, Dyal L, Yusuf S, Gerstein HC; ORIGIN Trial Investigators. Association of handgrip strength to cardiovascular mortality in pre-diabetic and diabetic patients: a subanalysis of the ORIGIN trial. Int $\mathrm{J}$ Cardiol 2014;174:458-461.

43. Holmes MD, Pollak MN, Willett WC, Hankinson SE. Dietary correlates of plasma insulinlike growth factor I and insulin-like growth factor binding protein 3 concentrations. Cancer Epidemiol Biomarkers Prev 2002;11:852-861.

44. Taekema DG, Ling CH, Blauw GJ, Meskers CG, Westendorp RG, de Craen AJ, Maier AB. Circulating levels of IGF1 are associated with muscle strength in middle-aged- and oldest-old women. Eur J Endocrinol 2011;164:189-196.

45. Roberts HC, Denison HJ, Martin HJ, Patel HP, Syddall H, Cooper C, Sayer AA. A review of the measurement of grip strength in clinical and epidemiological studies: towards a standardised approach. Age Ageing 2011;40:423-429.

46. Mehta RS, Abu-Ali GS, Drew DA, Lloyd-Price J, Subramanian A, Lochhead P, Joshi AD, Ivey KL, Khalili H, Brown GT, DuLong C, Song M, Nguyen LH, Mallick H, Rimm EB, Izard J, Huttenhower C, Chan AT. Stability of the human faecal microbiome in a cohort of adult men. Nat Microbiol 2018;3:347-355. 
47. Faith JJ, Guruge JL, Charbonneau M, Subramanian S, Seedorf H, Goodman AL, Clemente JC, Knight R, Heath AC, Leibel RL, Rosenbaum M, Gordon Jl. The long-term stability of the human gut microbiota. Science $2013 ; 341: 1237439$

48. Rinninella E, Raoul P, Cintoni M, Franceschi F, Miggiano GAD, Gasbarrini A, Mele MC. What is the Healthy Gut Microbiota Composition? A Changing Ecosystem across Age, Environment, Diet, and Diseases. Microorganisms 2019;7:pii: E14

49. Paoli A, Mancin L, Bianco A, Thomas E, Mota JF, Piccini F. Ketogenic diet and microbiota: friends or enemies? Genes (Basel) 2019;15: E534.

50. Zhang Y, Zhou S, Zhou Y, Yu L, Zhang L, Wang Y. Altered gut microbiome composition in children with refractory epilepsy after ketogenic diet. Epilepsy Res 2018;145:163-168.

51. Xie G, Zhou Q, Qiu CZ, Dai WK, Wang HP, Li YH, Liao JX, Lu XG, Lin SF, Ye JH, Ma ZY, Wang WJ. Ketogenic diet poses a significant effect on imbalanced gut microbiota in infants with refractory epilepsy. World J Gastroenterol 2017;23:6164-6171.

52. Madsen L, Myrmel LS, Fjære E, Liaset B, Kristiansen K. Links between dietary protein sources, the gut microbiota, and obesity. Front Physiol 2017;8:1047.

53. Blachier F, Beaumont M, Portune KJ, Steuer N, Lan A, Audebert M, Khodorova N, Andriamihaja M, Airinei G, Benamouzig R, Davila AM, Armand L, Rampelli S, Brigidi P, Tomé D, Claus SP, Sanz Y. High-protein diets for weight management: Interactions with the intestinal microbiota and consequences for gut health. A position paper by the my new gut study group. Clin Nutr. 2019;38:1012-1022.

54. Kar SK, Jansman AJM, Benis N, Ramiro-Garcia J, Schokker D, Kruijt L, Stolte EH, Taverne-Thiele JJ, Smits MA, Wells JM. Dietary protein sources differentially affect microbiota, mTOR activity and transcription of mTOR signaling pathways in the small intestine. PLoS One 2017;12:e0188282. 
55. Zhu Y, Lin X, Zhao F, Shi X, Li H, Li Y, Zhu W, Xu X, Li C, Zhou G. Meat, dairy and plant proteins alter bacterial composition of rat gut bacteria. Sci Rep 2015;5:15220.

56. Li R, Chang L, Hou G, Song Z, Fan Z, He X, Hou DX. Colonic microbiota and metabolites response to different dietary protein sources in a piglet model. Front Nutr $2019 ; 6: 151$.

57. Clemente JC, Ursell LK, Parfrey LW, Knight R. The impact of the gut microbiota on human health: an integrative view. Cell 2012;148:1258-1270.

58. Lloyd-Price J, Abu-Ali G, Huttenhower C. The healthy human microbiome. Genome Med 2016;8:51.

59. Maruvada P, Leone V, Kaplan LM, Chang EB. The Human Microbiome and Obesity:

Moving beyond Associations. Cell Host Microbe 2017;22:589-599.

60. Brunkwall L, Orho-Melander M. The gut microbiome as a target for prevention and treatment of hyperglycaemia in type 2 diabetes: from current human evidence to future possibilities. Diabetologia 2017;60:943-951.

61. Gilbert JA, Blaser MJ, Caporaso JG, Jansson JK, Lynch SV, Knight R. Current understanding of the human microbiome. Nat Med 2018;24:392-400.

62. Paoli A, Rubini A, Volek JS, Grimaldi KA. Beyond weight loss: a review of the therapeutic uses of very-low-carbohydrate (ketogenic) diets. Eur J Clin Nutr 2013;67:789796.

63. Bruci A, Tuccinardi D, Tozzi R, Balena A, Santucci S, Frontani R, Mariani S, Basciani S, Spera G, Gnessi L, Lubrano C, Watanabe M. Very Low-Calorie Ketogenic Diet: A Safe and Effective Tool for Weight Loss in Patients With Obesity and Mild Kidney Failure. Nutrients. 2020 Jan 27;12(2). pii: E333. 


\section{Figure legends}

Figure 1. Flow diagram of the study. A total of 350 individuals were screened. The subjects enrolled were randomized to either a VLCKD dietary intervention group with whey protein, a VLCKD dietary intervention group with vegetable protein or a VLCKD dietary intervention group with animal protein.

Figure 2. Box plot of pooled ranking of all observed relative differences (\% variation vs. basal values) from day 0 to day 45 in BUN, creatinine, eGFR, uric acid, $H G$, and IGF1 values in the WPG, the VPG and the APG. The $P$ values of the parameters plotted are shown in table 2.

Figure 3. Correlation between VLCK dietary interventions and gut microbial ecology. (A) Relative abundance of bacterial phyla in each sample among each treatment group $(n=7)$ at time 0 and after 45 days of VLCKD dietary intervention (group 1, VLCKD with whey protein; group 2, VLCKD with vegetable protein; group 3, VLCKD with animal protein). (B) Relative abundance of Bacteroidetes and Firmicutes. For each time point, values from all available samples were averaged ( $\mathrm{n}$ was 21 per time point). Mean values \pm SDs are plotted. ${ }^{* * *}=$ $\mathrm{p}<0.0001$ 
Figure 4. Effect of 45-day VLCKD dietary interventions with whey protein (white bars), vegetable protein (green bars) and animal protein (red bars) on the relative abundance of Firmicutes and Bacteroidetes. For each time point, values from all available samples were averaged ( $n$ was 7 per time point). Mean values \pm SDs are plotted. ${ }^{*}=p<0.017 ;{ }^{* *}=$ $p<0.0023 ;^{* * *}=p<0.001$ 
Table 1. Participant characteristics at baseline (TO) and after 45 days (T45) of VLCKD consumption (whey protein group, WPG; vegetable protein group, VPG; animal protein group, APG)

\begin{tabular}{|c|c|c|c|c|c|c|c|c|c|}
\hline & \multicolumn{2}{|c|}{ WPG } & \multirow[b]{2}{*}{$\mathbf{P}$} & \multicolumn{2}{|c|}{ VPG } & \multirow[b]{2}{*}{$\mathbf{P}$} & \multicolumn{2}{|c|}{ APG } & \multirow[b]{2}{*}{$\mathbf{P}$} \\
\hline & TO & T45 & & TO & T45 & & TO & T45 & \\
\hline BW (kg) & $\begin{array}{c}102.02 \pm \\
12.04\end{array}$ & $\begin{array}{c}94.05 \pm \\
11.43\end{array}$ & $\begin{array}{c}0.03 \\
2\end{array}$ & $\begin{array}{c}102.10 \pm \\
12.36\end{array}$ & $\begin{array}{c}94.08 \pm \\
11.92\end{array}$ & 0.041 & $\begin{array}{c}98.36 \pm \\
14.49\end{array}$ & $\begin{array}{c}91.72 \pm \\
14.48\end{array}$ & 0.106 \\
\hline BMI $\left(\mathrm{kg} / \mathrm{m}^{2}\right)$ & $35.8 \pm 5.0$ & $32.6 \pm 4.8$ & $\begin{array}{c}0.03 \\
5\end{array}$ & $36.1 \pm 4.3$ & $32.9 \pm 4.0$ & 0.020 & $35.7 \pm 3.7$ & $32.8 \pm 3.7$ & 0.016 \\
\hline WC $(\mathrm{cm})$ & $110.0 \pm 9.4$ & $102.8 \pm 8.4$ & $\begin{array}{c}0.01 \\
4\end{array}$ & $108.2 \pm 8.5$ & $102.5 \pm 7.6$ & 0.031 & $\begin{array}{c}105.3 \pm \\
9.1\end{array}$ & $99.1 \pm 10.2$ & 0.040 \\
\hline $\mathrm{HC}(\mathrm{cm})$ & $\begin{array}{c}123.6 \pm \\
12.1\end{array}$ & $\begin{array}{c}117.9 \pm \\
12.2\end{array}$ & $\begin{array}{c}0.09 \\
8\end{array}$ & $123.3 \pm 9.3$ & $117.9 \pm 8.4$ & 0.049 & $\begin{array}{c}122.5 \pm \\
10.6\end{array}$ & $\begin{array}{c}116.1 \pm \\
10.3\end{array}$ & 0.047 \\
\hline $\mathrm{TC}(\mathrm{cm})$ & $63.6 \pm 5.3$ & $59.7 \pm 5.2$ & $\begin{array}{c}0.02 \\
2\end{array}$ & $64.1 \pm 5.3$ & $60.5 \pm 5.9$ & 0.043 & $65.4 \pm 7.2$ & $62.1 \pm 6.6$ & 0.091 \\
\hline $\begin{array}{l}\text { Arm circumference } \\
(\mathrm{cm})\end{array}$ & $36.6 \pm 3.9$ & $34.6 \pm 3.7$ & $\begin{array}{c}0.07 \\
2\end{array}$ & $36.3 \pm 3.7$ & $34.5 \pm 3.4$ & 0.083 & $37.7 \pm 3.0$ & $35.6 \pm 2.9$ & 0.029 \\
\hline Systolic BP (mmHg) & $132 \pm 10$ & $124 \pm 13$ & $\begin{array}{c}0.03 \\
2\end{array}$ & $131 \pm 8$ & $121 \pm 10$ & 0.005 & $129 \pm 9$ & $121 \pm 16$ & 0.036 \\
\hline Diastolic BP (mmHg) & $78 \pm 11$ & $70 \pm 9$ & $\begin{array}{c}0.02 \\
0\end{array}$ & $78 \pm 10$ & $72 \pm 10$ & 0.030 & $78 \pm 10$ & $71 \pm 9$ & 0.014 \\
\hline $\begin{array}{l}\text { Fasting glycemia } \\
\mathrm{mg} / \mathrm{dL}\end{array}$ & $\begin{array}{c}108.1 \pm \\
22.3\end{array}$ & $94.1 \pm 11.4$ & $\begin{array}{c}0.01 \\
7\end{array}$ & $\begin{array}{c}106.5 \pm \\
17.6\end{array}$ & $\begin{array}{c}100.9 \pm \\
17.6\end{array}$ & 0.193 & $\begin{array}{l}99.7 \pm \\
12.9\end{array}$ & $92.6 \pm 9.2$ & 0.042 \\
\hline $\begin{array}{l}\text { Fasting insulin } \\
(\mu \mathrm{IU} / \mathrm{ml})\end{array}$ & $25.0 \pm 18.9$ & $8.5 \pm 4.1$ & $\begin{array}{c}0.00 \\
1\end{array}$ & $19.4 \pm 7.4$ & $8.3 \pm 4.7$ & 0.000 & $17.7 \pm 8.7$ & $6.8 \pm 4.1$ & 0.000 \\
\hline HOMA-IR (ng/ml) & $4.15 \pm 1.34$ & $2.1 \pm 1.2$ & $\begin{array}{c}0.00 \\
4\end{array}$ & $5.1 \pm 2.0$ & $2.1 \pm 1.2$ & 0.000 & $\begin{array}{c}4.05 \pm \\
1.72\end{array}$ & $1.6 \pm 1.1$ & 0.000 \\
\hline IGF-1 (ng/ml) & $\begin{array}{c}141.4 \pm \\
15.91\end{array}$ & $\begin{array}{c}167.46 \pm \\
43.15\end{array}$ & $\begin{array}{c}0.01 \\
8\end{array}$ & $\begin{array}{c}159.82 \pm \\
19.25\end{array}$ & $\begin{array}{c}116.52 \pm \\
22.05\end{array}$ & 0.000 & $\begin{array}{c}132.88 \pm \\
26.92\end{array}$ & $\begin{array}{c}148.86 \pm \\
32.15\end{array}$ & 0.160 \\
\hline Creatinine (mg/dl) & $0.90 \pm 0.30$ & $0.79 \pm 0.22$ & 0.12 & $0.78 \pm 0.17$ & $0.78 \pm 0.15$ & 0.465 & $\begin{array}{c}0.80 \pm \\
0.16\end{array}$ & $0.86 \pm 0.19$ & 0.163 \\
\hline BUN (mg/dl) & $39.0 \pm 12.5$ & $38.5 \pm 13.9$ & $\begin{array}{c}0.46 \\
6\end{array}$ & $40.0 \pm 13.1$ & $37.4 \pm 12.1$ & 0.281 & $39.3 \pm 6.8$ & $48.0 \pm 14.4$ & 0.019 \\
\hline eGFR (ml/min) & $\begin{array}{c}131.9 \pm \\
42.9\end{array}$ & $\begin{array}{c}136.6 \pm \\
56.1\end{array}$ & $\begin{array}{c}0.39 \\
5\end{array}$ & $\begin{array}{c}146.4 \pm \\
33.3\end{array}$ & $\begin{array}{c}131.4 \pm \\
26.8\end{array}$ & 0.091 & $\begin{array}{c}134.8 \pm \\
33.2\end{array}$ & $\begin{array}{c}115.6 \pm \\
30.2\end{array}$ & 0.049 \\
\hline Proteins (g/L) & $74.3 \pm 4.0$ & $71.8 \pm 2.9$ & $\begin{array}{c}0.02 \\
8\end{array}$ & $75.0 \pm 3.5$ & $74.0 \pm 4.1$ & 0.237 & $74.3 \pm 4.4$ & $72.2 \pm 3.5$ & 0.070 \\
\hline Albumin (g/L) & $\begin{array}{c}44.13 \pm \\
2.43\end{array}$ & $\begin{array}{c}43.71 \pm \\
2.90\end{array}$ & $\begin{array}{c}0.32 \\
8\end{array}$ & $\begin{array}{c}44.55 \pm \\
2.76\end{array}$ & $\begin{array}{c}43.98 \pm \\
2.69\end{array}$ & 0.283 & $\begin{array}{c}44.68 \pm \\
2.71\end{array}$ & $\begin{array}{c}44.22 \pm \\
1.91\end{array}$ & 0.293 \\
\hline AST (U/L) & $23.8 \pm 13.0$ & $19.9 \pm 5.8$ & $\begin{array}{c}0.14 \\
6\end{array}$ & $25.3 \pm 13.2$ & $26.8 \pm 14.0$ & 0.385 & $19.8 \pm 4.7$ & $19.9 \pm 3.7$ & 0.450 \\
\hline $\operatorname{ALT}(U / L)$ & $31.1 \pm 15.4$ & $24.0 \pm 9.3$ & $\begin{array}{c}0.06 \\
2\end{array}$ & $35.0 \pm 24.0$ & $35.5 \pm 26.9$ & 0.479 & $23.8 \pm 7.0$ & $21.6 \pm 4.9$ & 0.151 \\
\hline HSI & $44.0 \pm 5.1$ & $41.6 \pm 5.4$ & $\begin{array}{c}0.10 \\
1\end{array}$ & $44.1 \pm 5.4$ & $40.9 \pm 5.2$ & 0.049 & $44.3 \pm 4.4$ & $42.1 \pm 4.1$ & 0.077 \\
\hline Uric acid (mg/dl) & $5.4 \pm 1.1$ & $5.1 \pm 1.4$ & $\begin{array}{c}0.25 \\
7\end{array}$ & $5.2 \pm 1.0$ & $5.8 \pm 1.1$ & 0.072 & $4.9 \pm 1.0$ & $5.6 \pm 0.8$ & 0.021 \\
\hline CRP ( $\mu \mathrm{g} / \mathrm{L})$ & $\begin{array}{c}4700 \pm \\
6740\end{array}$ & $\begin{array}{c}2662 \pm \\
2414\end{array}$ & $\begin{array}{c}0.13 \\
2\end{array}$ & $\begin{array}{c}7050 \pm \\
5959\end{array}$ & $\begin{array}{c}5913 \pm \\
6435\end{array}$ & 0.307 & $\begin{array}{c}5156 \pm \\
4820\end{array}$ & $\begin{array}{c}4087 \pm \\
3383\end{array}$ & 0.237 \\
\hline ESR (mm/h) & $26.8 \pm 16.0$ & $28.5 \pm 15.8$ & $\begin{array}{c}0.37 \\
9\end{array}$ & $28.0 \pm 17.9$ & $25.7 \pm 17.1$ & 0.357 & $\begin{array}{c}28.8 \pm \\
15.8\end{array}$ & $26.1 \pm 12.1$ & 0.292 \\
\hline $\begin{array}{l}\text { Total cholesterol } \\
\text { (mg/dl) }\end{array}$ & $\begin{array}{c}214.8 \pm \\
31.5\end{array}$ & $\begin{array}{c}166.2 \pm \\
43.6\end{array}$ & $\begin{array}{c}0.00 \\
1\end{array}$ & $\begin{array}{c}220.9 \pm \\
51.6\end{array}$ & $\begin{array}{c}170.7 \pm \\
36.3\end{array}$ & 0.002 & $\begin{array}{c}226.9 \pm \\
32.7\end{array}$ & $\begin{array}{c}191.2 \pm \\
34.2\end{array}$ & 0.003 \\
\hline $\begin{array}{l}\text { LDL cholesterol } \\
(\mathrm{mg} / \mathrm{dl})\end{array}$ & $\begin{array}{c}132.8 \pm \\
30.8\end{array}$ & $\begin{array}{c}100.8 \pm \\
38.4\end{array}$ & $\begin{array}{c}0.00 \\
8\end{array}$ & $\begin{array}{c}136.1 \pm \\
41.3\end{array}$ & $97.5 \pm 32.3$ & 0.004 & $\begin{array}{c}143.9 \pm \\
25.8\end{array}$ & $\begin{array}{c}118.5 \pm \\
23.1\end{array}$ & 0.003 \\
\hline Triglycerides (mg/dl) & $\begin{array}{c}131.0 \pm \\
44.9\end{array}$ & $94.6 \pm 32.0$ & $\begin{array}{c}0.00 \\
7\end{array}$ & $\begin{array}{c}170.1 \pm \\
126.9\end{array}$ & $\begin{array}{c}117.6 \pm \\
42.7\end{array}$ & 0.069 & $\begin{array}{c}124.25 \pm \\
58\end{array}$ & $\begin{array}{c}82.25 \pm \\
33.32\end{array}$ & 0.009 \\
\hline $\begin{array}{l}\text { HDL cholesterol } \\
\text { (mg/dl) }\end{array}$ & $51.7 \pm 12.3$ & $46.1 \pm 7.5$ & $\begin{array}{c}0.07 \\
2\end{array}$ & $51.2 \pm 12.8$ & $49.0 \pm 9.5$ & 0.298 & $\begin{array}{c}57.9 \pm \\
23.7\end{array}$ & $56.2 \pm 18.0$ & 0.408 \\
\hline $\begin{array}{l}\text { Urine acetoacetic } \\
\text { acid }(\mathrm{mg} / \mathrm{dL})\end{array}$ & $1.8 \pm 0.8$ & $56.3 \pm 31.3$ & $\begin{array}{c}0.00 \\
0\end{array}$ & $1.8 \pm 0.7$ & $41.1 \pm 15.4$ & 0.000 & $1.6 \pm 0.7$ & $44.8 \pm 15.3$ & 0.000 \\
\hline
\end{tabular}




\begin{tabular}{|c|c|c|c|c|c|c|c|c|c|}
\hline Total fat (kg) & $\begin{array}{c}36.74 \pm \\
10.83\end{array}$ & $\begin{array}{c}31.92 \pm \\
10.19\end{array}$ & $\begin{array}{c}0.10 \\
2\end{array}$ & $\begin{array}{c}37.40 \pm \\
7.77\end{array}$ & $\begin{array}{c}32.00 \pm \\
7.51\end{array}$ & 0.081 & $\begin{array}{c}37.00 \pm \\
8.23\end{array}$ & $\begin{array}{c}32.85 \pm \\
8.88\end{array}$ & 0.094 \\
\hline Total lean (kg) & $\begin{array}{c}62.95 \pm \\
9.04\end{array}$ & $\begin{array}{c}59.93 \pm \\
7.66\end{array}$ & $\begin{array}{c}0.15 \\
8\end{array}$ & $\begin{array}{c}62.32 \pm \\
1.04\end{array}$ & $\begin{array}{c}59.70 \pm \\
10.02\end{array}$ & 0.246 & $\begin{array}{c}57.24 \pm \\
9.21\end{array}$ & $\begin{array}{c}56.59 \pm \\
12.18\end{array}$ & 0.434 \\
\hline Total fat (\%) & $\begin{array}{c}35.71 \pm \\
8.38\end{array}$ & $\begin{array}{c}33.33 \pm \\
8.33\end{array}$ & $\begin{array}{c}0.21 \\
3\end{array}$ & $\begin{array}{c}36.69 \pm \\
6.46\end{array}$ & $\begin{array}{c}34.06 \pm \\
6.82\end{array}$ & 0.144 & $\begin{array}{c}37.75 \pm \\
6.87\end{array}$ & $\begin{array}{c}35.89 \pm \\
8.04\end{array}$ & 0.247 \\
\hline Total lean (\%) & $\begin{array}{c}62.01 \pm \\
8.01\end{array}$ & $\begin{array}{c}64.13 \pm \\
7.88\end{array}$ & $\begin{array}{c}0.43 \\
8\end{array}$ & $\begin{array}{c}60.96 \pm \\
6.29\end{array}$ & $\begin{array}{c}63.41 \pm \\
6.59\end{array}$ & 0.072 & $\begin{array}{c}58.57 \pm \\
7.60\end{array}$ & $\begin{array}{c}61.63 \pm \\
7.99\end{array}$ & 0.026 \\
\hline Trunk fat (kg) & $\begin{array}{c}18.40 \pm \\
5.54\end{array}$ & $\begin{array}{c}15.43 \pm \\
5.01\end{array}$ & $\begin{array}{c}0.02 \\
2\end{array}$ & $\begin{array}{c}18.69 \pm \\
3.36\end{array}$ & $\begin{array}{c}15.96 \pm \\
3.24\end{array}$ & 0.016 & $\begin{array}{c}17.43 \pm \\
3.27\end{array}$ & $\begin{array}{c}15.46 \pm \\
3.80\end{array}$ & 0.065 \\
\hline HG (kg) & $\begin{array}{c}32.47 \pm \\
7.73\end{array}$ & $\begin{array}{c}34.45 \pm \\
7.34\end{array}$ & 0.23 & $\begin{array}{c}30.13 \pm \\
6.99\end{array}$ & $\begin{array}{c}31.01 \pm \\
6.92\end{array}$ & 0.36 & $\begin{array}{c}32.64 \pm \\
9.04\end{array}$ & $\begin{array}{c}34.03 \pm \\
9.25\end{array}$ & 0.33 \\
\hline
\end{tabular}

Abbreviations: BW, body weight; BMI, body mass index; WC, waist circumference; HC, hip circumference; TC, thigh circumference; BP, blood pressure; HOMA-IR, homeostasis model assessment- insulin resistance; BUN, blood urea nitrogen; eGFR, estimated glomerular filtration rate; AST, aspartate transaminase; ALT, alanine transferase; HSI, hepatic steatosis index; CRP, Creactive protein; ESR, erythrocyte sedimentation rate; HG, handgrip strength. Values in bold indicate statistically significant results $(\mathrm{P} \leq 0.05)$. 
Table 2. Between-group (ANCOVA) and within-group (ANOVA) P values of the percent change from baseline of the parameters with a significant group effect measured after 45 days of VLCKD consumption (whey protein group, WPG; vegetable protein group, VPG; animal protein group, APG).

\begin{tabular}{lcccc}
\hline & Between groups & WPG vs VPG & WPG vs APG & A PG vs VPG \\
\hline IGF-1 & $\mathbf{0 . 0 0 0 0}$ & $\mathbf{0 . 0 0 0 0}$ & 0.5697 & 0.0011 \\
\hline Creatinine & $\mathbf{0 . 0 0 1 0}$ & $\mathbf{0 . 0 6 9 6}$ & $\mathbf{0 . 0 0 0 6}$ & 0.2004 \\
\hline BUN & $\mathbf{0 . 0 0 1 9}$ & 0.2281 & $\mathbf{0 . 0 9 7 3}$ & $\mathbf{0 . 0 0 1 3}$ \\
\hline eGFR & $\mathbf{0 . 0 0 1 6}$ & $\mathbf{0 . 0 3 3 4}$ & $\mathbf{0 . 0 0 1 3}$ & 0.4690 \\
\hline Uric acid & $\mathbf{0 . 0 1 1 2}$ & $\mathbf{0 . 0 5 3 3}$ & $\mathbf{0 . 0 1 2 8}$ & 0.8316 \\
\hline HG & $\mathbf{0 . 0 0 4 0}$ & $\mathbf{0 . 0 0 2 7}$ & 0.1351 & 0.2652 \\
\hline
\end{tabular}

Abbreviations: BUN, blood urea nitrogen; eGFR, estimated glomerular filtration rate; HG, handgrip strength; AL商 appendicular lean mass; DALM, dominant arm lean mass.

Values in bold indicate statistically significant results $(\mathrm{P} \leq 0.05)$ and values "trending towards significance" $(\mathrm{P}<0.1)$. 
Table 3. Adverse events during the nutritional interventions (WPG, VLCKD incorporating whey protein; VPG, VLCKD incorporating vegetable protein; APG, VLCKD incorporating animal protein) recorded 15 days (T15) and 45 days (T45) after the start of the diets. Number (percentage) of participants reporting an adverse event.

\begin{tabular}{lcccccc}
\hline & \multicolumn{2}{c}{ WPG } & \multicolumn{2}{c}{ VPG } & \multicolumn{2}{c}{ APG } \\
\hline constipation & $2(12.5)$ & $4(25)$ & $2(12.5)$ & $4(25)$ & $2(12.5)$ & $6(37.5)$ \\
\hline diarrhea & $1(0.6)$ & $1(0.6)$ & $3(18.7)$ & $2(12.5)$ & $1(0.6)$ & $2(12.5)$ \\
\hline cramps & $1(0.6)$ & $1(0.6)$ & $2(12.5)$ & $1(0.6)$ & $1(0.6)$ & $1(0.6)$ \\
\hline nausea & $2(12.5)$ & $2(12.5)$ & $2(12.5)$ & $1(0.6)$ & $1(0.6)$ & $1(0.6)$ \\
\hline fatigue & $1(0.6)$ & $1(0.6)$ & $3(18.7)$ & $2(12.5)$ & $2(12.5)$ & $1(0.6)$ \\
\hline hunger & $3(18.7)$ & $3(18.7)$ & $2(12.5)$ & $2(12.5)$ & $3(18.7)$ & $2(12.5)$ \\
\hline headache & $4(25)$ & $1(0.6)$ & $2(12.5)$ & $1(0.6)$ & $2(12.5)$ & $2(12.5)$ \\
\hline dizziness & $2(12.5)$ & $2(12.5)$ & $2(12.5)$ & $1(0.6)$ & $1(0.6)$ & $1(0.6)$ \\
insomnia & $1(0.6)$ & $1(0.6)$ & $1(0.6)$ & $2(12.5)$ & $2(12.5)$ & $2(12.5)$ \\
\hline
\end{tabular}


Figure 1

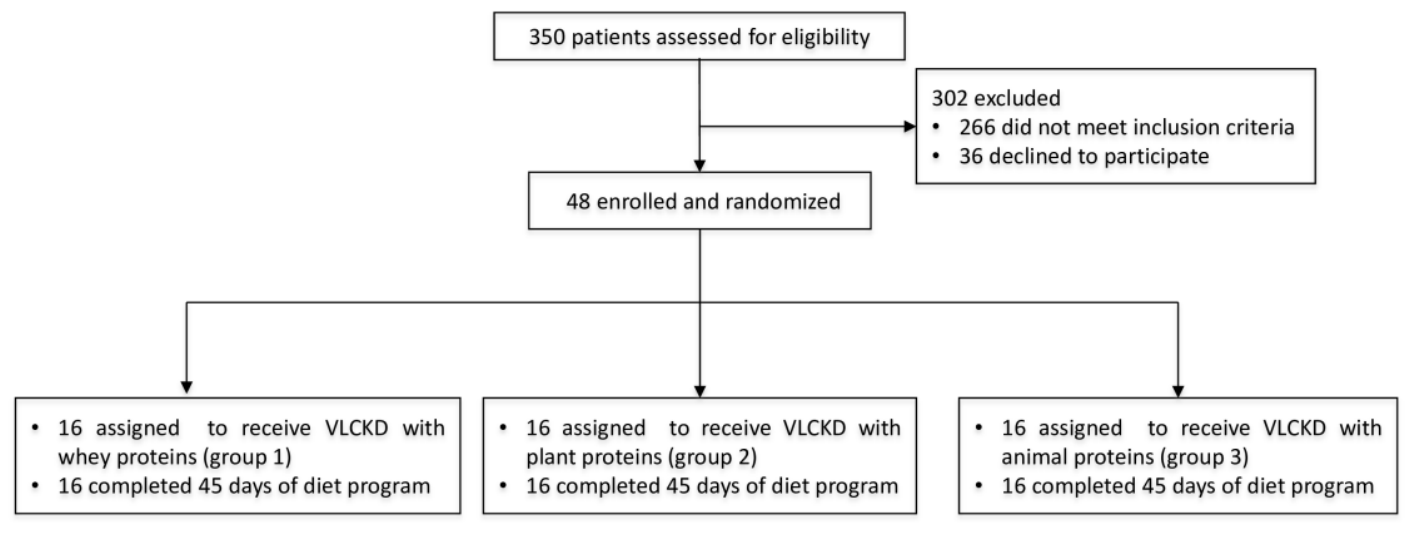


Figure 2

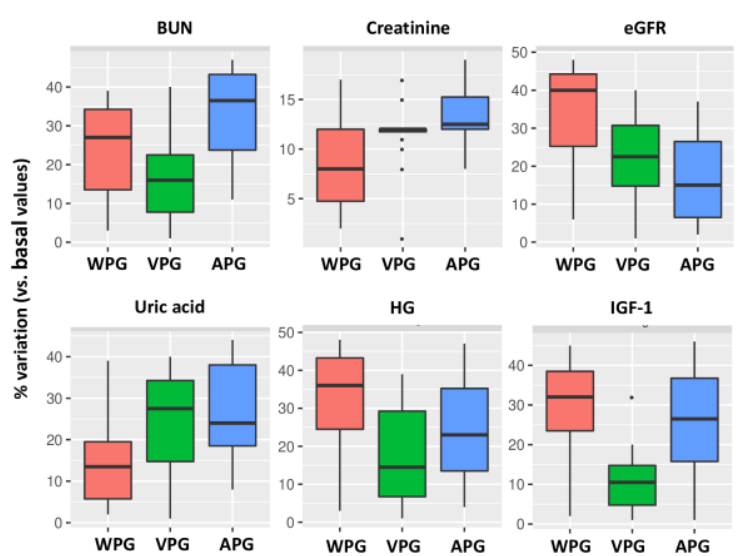


Figure 3
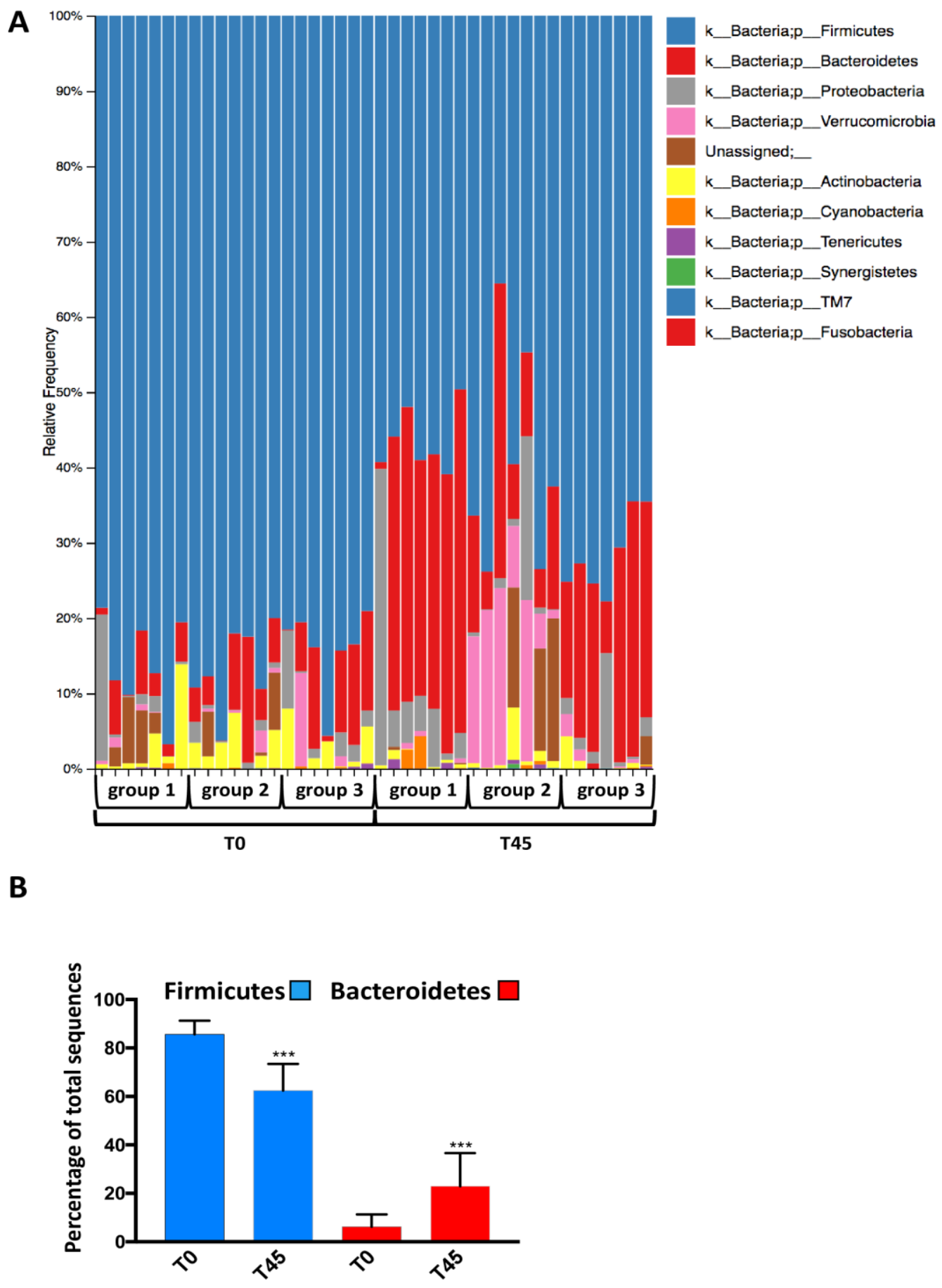
Figure 4

Firmicutes

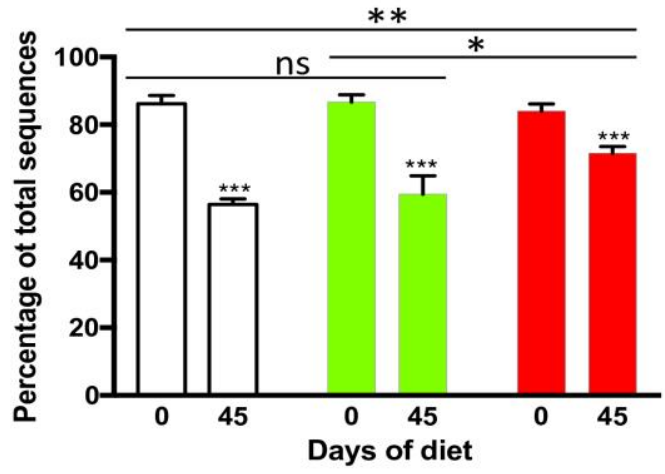

\section{Bacteroidetes}

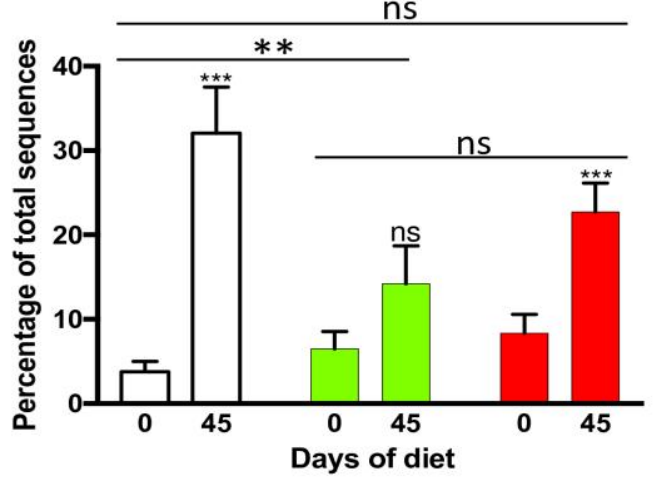

